\title{
Mikrosporidialar ve Mikrosporidiyozis
}

\author{
Microsporidia and Microsporidiosis
}

\section{Süleyman Yazar1', Özgür Koru², Berna Hamamcı', Ülfet Çetinkaya'1, Ülkü Karaman³, Salih Kuk'}

'Erciyes Üniversitesi Tıp Fakültesi, Parazitoloji Anabilim Dalı, Kayseri, Türkiye

${ }^{2}$ Gülhane Askeri Tıp Akademisi, Parazitoloji Bilim Dalı, Ankara, Türkiye

${ }^{3}$ Ordu Üniversitesi Sağlık Yüksek Okulu, Hemşirelik Bölümü, Ordu, Türkiye

\section{ÖZET}

Mikrosporidialar, zorunlu hücre içi parazitidirler ve konak hücresi dışında metabolik aktivasyon göstermemektedirler. Ökaryotik hücrelerdir, fakat bazı tipik ökaryotik özellikler eksiktir. Şimdiye kadar tanımlamış 144 cins içinde 1200'den fazla türü vardır. Mikrosporidiaların en çok bilinene evresi küçük ve oldukça dirençli olan sporlarıdır. Boyutları türe göre farklıık gösterir ama genellikle 1-10 $\mu m$ arasındadır. Mikrosporodiaların hayatları üç fazda incelenebilir; enfektif veya çevresel faz, proliferatif veya üreme fazı ve sporogonik faz. Mikrosporidiaların tanısında Işık mikroskobu, Transmisyon Elektron Mikroskobu (TEM), Immünofloresan tekniği (IFA) ve Moleküler yöntemler gibi değişik metotlar kullanılmaktadır. Klinik semptomlar, enfeksiyonun lokalizasyonu ve konağın immün durumu ile yakından ilişkilidir. İnsanlarda görülen mikrosporidiosis önemli ve hızlı gelişen fırsatçı bir hastalıktır özellikle de AIDS'li immunocompromise hastalarda daha ciddi seyretmektedir. Mikrosporidiosis'in tedavisi genellikle ilaç ve destek tedavi ile sağlanmaktadır. Enfeksiyona ve türüne bağlı olarak farklı ilaçlar kullanılmaktadır. Tedavide en yaygın olarak albendazol ve fumagilin kullanıldığı belirtilmektedir. (Turkiye Parazitol Derg 2013; 37: 123-34)

Anahtar Sözcükler: Mikrosporidia, mikrosporidiyozis, tanı yöntemleri, klinik

Geliş Tarihi: 02.01.2013 Kabul Tarihi: 19.02.2013

\section{ABSTRACT}

All microsporidia are obligate parasites and have no active stages outside their host cells. Microsporidia lack some typical eukaryotic characteristics. There are now over 1200 species identified in 144 genera. The most familiar stage of microsporidia is the small, highly resistant spore, the size of which differs according to the species and is often 1-10 $\mu \mathrm{m}$. The general life cycle pattern of the microsporidia can be divided into three phases: the infective or environmental phase, the proliferative phase, and the sporogony or spore-forming phase. There are several methods for diagnosing microsporidia: light microscopic, transmission electron microscopy (TEM), immunofluorescence assays (IFA) and molecular methods. The clinical course of microsporidiosis depends on the immune status of the host and site of infection. Microsporidia can cause infections such as diarrhoea, keratitis, myositis, bronchitis and brochiolitis. Human microsporidiosis represents an important and rapidly emerging opportunistic disease, occurring mainly, but not exclusively, in severely immunocompromised patients with AIDS. The treatment of microsporidiosis is generally achieved with medications and supportive care. Depending on the site of infection and the microsporidia species involved, different medications are utilized. The most commonly used medications for microsporidiosis include albendazole and fumagillin. (Turkiye Parazitol Derg 2013; 37: 123-34)

Key Words: Microsporidia, microsporidiosis, diagnosis methods, clinic

Received: 02.01.2013

Accepted: 19.02 .2013

\section{Bu çalışma 1-7 Kasım 2009 tarihlerinde Adana'da gerçekleşen XVI. Ulusal Parazitoloji Kongresi'nde sunulmuştur.} This study was presented at the XVI. National Parasitology Congress in Adana, 1-7 November-2009.

Yazışma Adresi / Address for Correspondence: Dr. Süleyman Yazar, Erciyes Üniversitesi Tıp Fakültesi, Parazitoloji Anabilim Dalı, Kayseri, Türkiye Tel: +903524374937 E-posta: syazar@erciyes.edu.tr

doi:10.5152/tpd.2013.28 


\section{GiRiş}

Mikrosporidialar, spor oluşturan zorunlu hücre içi parazitidirler (1). Ökaryotik hücre olarak tanımlanmalarıyla birlikte bazı tipik ökaryotik özelliklerden yoksundurlar. Ribozom (70S), ribozomal alt ünite (30S ve 50S) ve rRNA bölge (16S ve 23S) özellikleri ve mitokondri, peroksizom ve tipik bir golgi aygıtına sahip olmamaları ile prokaryotik organizmalara benzerlerken, zarla çevrili bir çekirdek, intrasitoplazmik membran sistemi ve mitotik iğciklerle gerçekleşen kromozomal bölünme özellikleriyle de ökaryotik organizma olarak değerlendirilmektedirler $(2,3)$.

Bugüne kadar 144 cinse bağlı 1200 den fazla türü tanımlanan bu protozoonlar hem omurgalı hem de omurgasız canlılarda enfeksiyon oluşturabilmektedirler. Bu nedenle tarih boyunca ipek böcekçiliği, bal arıcılığı ve ticari balıkçılık sektörlerinde ciddi ekonomik sorunlara yol açarken kemiriciler, tavşanlar, kürk hayvanları ve primatlarda da önemli bir enfeksiyon ajanı olarak bildirilmişlerdir. Bununla birlikte bu organizmalar, çekirge gibi böceklerin biyolojik kontrollerinde de yararlı bir şekilde kullanılabilmektedirler $(1,3,4)$.

\section{Morfolojik Özellikleri}

\section{Spor Morfolojisi}

Mikrosporidiaların en tipik gelişimsel evresi, polar filament taşıyan spor dönemidir. Spor, muhtevasını konak hücre içine enjekte edebilme mekanizmasına sahip olan enfektif dönemdir ve konak hücre dışında uzun zaman yaşayabilen tek evrim dönemidir. Boyutları 1-20 $\mu \mathrm{m}^{\prime}$ dir. Memelileri enfekte eden sporlar daha küçük boyutlardadır (1-3 $\mu \mathrm{m})$. Oval, küresel, çubuk veya armut şeklinde olabilirler $(1,3)$.

Spor üç genel yapıya sahiptir (5). Bunlar; spor duvarı, sporoplazma ve ekstrüksiyon aygıtıdır (Şekil 1).

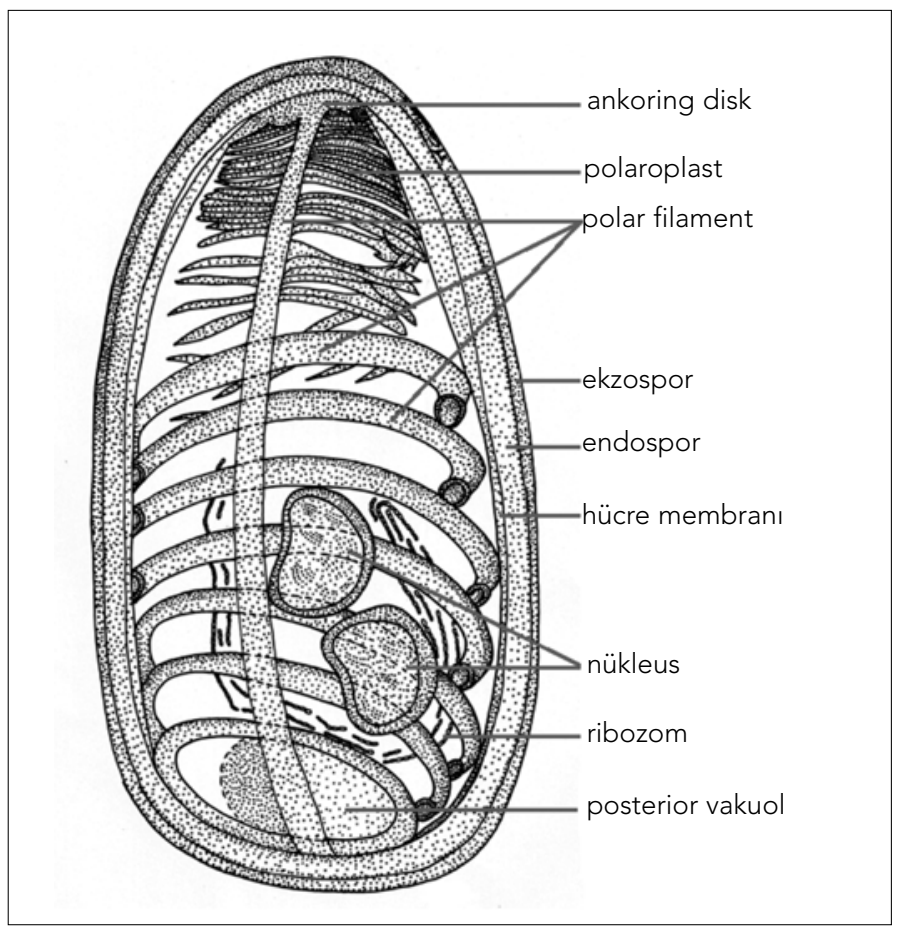

Şekil 1. Spor morfolojisi (Orjinal)

\section{Spor Duvar}

Çevresel direnç sağlayan spor duvarı, elektron mikroskopisi ile gözlenebilen üç tabakadan oluşmuştur. Bunlar; Ekzospor: Elektron-yoğun olan en dıştaki, glikoprotein yapısındaki tabakadır. Endospor: Elektron-fakir ve temel birleşeni kitin olan tabakadır. Ekzospora bir köprü ile bağlanmıştır. Endospor tabakasının anterior ucu sporun en ince kısmıdır ve polar tüpün dışarı çıkması esnasında parçalanır. Hücre membranı: Yaklaşık 7 nm kalınlığında olan ve sitoplazmayı kuşatan en içteki tabakadır $(1,3,5)$.

\section{Sporoplasma}

Spor sitoplazması bir veya iki çekirdekli nükleus, prokaryotik boyda ribozomlar, karakteristik bir şekilde konumlanmış endoplazmik retikulum içerir. Çekirdek ökaryotik tiptedir. Mitokondri, peroksizom ve tipik bir golgi aygıtına da sahip değillerdir $(1,3,5)$.

\section{Ekstrüzyon Aparatı}

Ekstrüzyon aparatı; sporun anterior ucundaki ankoring (çapa şeklinde) diske mantar şeklinde bağlanan uzun polar filament, polaroplast adı verilen atipik bir golgi cisimciği ve posterior vaküolden oluşmaktadır.

\section{Spor oluşumu öncesi evrim dönemleri}

Meront, sporont ve sporoblast mikrosporidiaların diğer evrim dönemleridir. Merontlar, büyük merkezi bir veya iki çekirdeğe sahip, bir plazma membranı ile kuşatılmış, yuvarlak veya hafif oval şekilli hücrelerdir. Stoplazma homojen olarak granüllüdür ve çok sayıda serbest ribozom ile az gelişmiş bir endoplazmik retikuluma sahiptir. Merontlar ikili veya daha fazla füzyonla çoğalarak sporontlara dönüşmektedir. Sporontlar ise sporoblasta dönüşür. Mikrosporidian gelişiminin tüm evreleri mitokondriden yoksundur $(6,7)$.

\section{Sinıflandırma}

Mikrosporidialar ilk olarak 1857'de Nageli tarafından Nosema bombycis olarak adlandırılmış; 1882 yılında Balbiani, mikrosporidia adı altında ayrı bir grup olarak sınıflandırmış; 1976 yılında Sprague, Mikrospora şubesi altında toplamış; 1980'de ise Protista alemi ve protozoa altalemi altında sınıflandırılmıştır (1, 4). Edling ve arkadaşları, alfa ve beta tubülin genlerinin dizi analizleri sonucunda mantarlara daha yakın olduklarını belirlemiş, fakat sınıflandırılması tam olarak aydınlatılamamıştır (8).

Mikrosporidiaların sınıflandırılmasındaki esas kriterler arasında; doğal konak ilişkileri, spor veya diğer gelişme dönemlerinin büyüklüğü, tek veya iki nükleusa sahip olması, spor içindeki polar filament helozon sayısı ve organizmanın konak hücre stoplazması ile ilişkisi yer almaktadır. Insanlarda enfeksiyon oluşturan türlerin morfolojik özellikleri Tablo 1'de verilmiştir $(8,9)$.

Microsporidium, tam belirgin olmayan mikrosporidia türleri için kullanılan ortak bir terimdir. Bu grup içerisinde insanı enfekte eden iki tür bulunmaktadır; $M$. ceylonensis ve $M$. ceylonensis sporları $3.5 \times 1.5 \mu \mathrm{m}$ boyutlarındadır ve polar tüpteki sarmal sayısı da 9'dur. M. africanum sporları ise 4.5-5 x 2.5-3 $\mu \mathrm{m}$ boyutlarındadır ve polar tüpteki sarmal sayısı da 11-13'tür $(1,10)$.

Insanlarda enfeksiyon oluşturan 7 cinse bağlı 14 tür tanımlanmıştır. Bu türlerin sınıflandırılması Şekil 2'de verilmiştir $(1,11)$. 
Tablo 1. Insanda enfeksiyon oluşturan mikrosporidia türlerinin taksonomik özellikleri (1, 8-10)

\begin{tabular}{|c|c|c|c|c|}
\hline Tür & Çekirdek yapısı & Gelişim yeri & Spor boyutu $(\mu \mathrm{m})$ & $\begin{array}{l}\text { Polar tüp } \\
\text { sarmal sayısı }\end{array}$ \\
\hline Encephalitozoon cuniculi & Tek parçalı & Parazitoforoz vakuol içinde & $2,5-3,2 \times 1,2-1,6$ & $4-7$ \\
\hline Encephalitozoon hellem & Tek parçalı & Parazitoforoz vakuol içinde & $2-2,5 \times 1-1,5$ & $6-8$ \\
\hline Encephalitozoon intestinalis & Tek parçalı & Parazitoforoz vakuol içinde & $2,2 \times 1,2$ & $5-7$ \\
\hline Enterocytozoon bieneusi & Tek parçalı & $\begin{array}{c}\text { Konak hücre sitoplazması ile } \\
\text { direkt temas halinde }\end{array}$ & $1,5 \times 0,5$ & $4-6$ \\
\hline Pleistophora sp. & Tek parçalı & Sporofor vezikül & $2,8 \times 3,4$ & $9-12$ \\
\hline Trachipleistophora hominis & Tek parçalı & Sporofor vezikül & $5,2 \times 2,4$ & 11 \\
\hline $\begin{array}{l}\text { Trachipleistophora } \\
\text { anthropophthera }\end{array}$ & Tek parçalı & Sporofor vezikül & $\begin{array}{l}\text { Tip I sporofor vezikül } \\
\text { sporlar; } 3,7 \times 2 \\
\text { Tip II sporofor vezikül } \\
\text { içindeki sporlar } 2,5 \times 1,4\end{array}$ & $4-5$ \\
\hline Vittaforma corneae & iki parçalı & $\begin{array}{l}\text { Konak hücre endoplazmik } \\
\text { retikulumu ile çevrelenmiş }\end{array}$ & $3,8 \times 1,2$ & $5-7$ \\
\hline Nosema ocularum & iki parçalı & $\begin{array}{l}\text { Konak hücre sitoplazması } \\
\text { ile direkt temas halinde }\end{array}$ & $5 \times 3$ & $9-12$ \\
\hline Brachiola sp. & İki parçalı & $\begin{array}{l}\text { Konak hücre sitoplazması } \\
\text { ile direkt temas halinde }\end{array}$ & $2,5-2,9 \times 1,9-2$ & $7-10$ \\
\hline
\end{tabular}
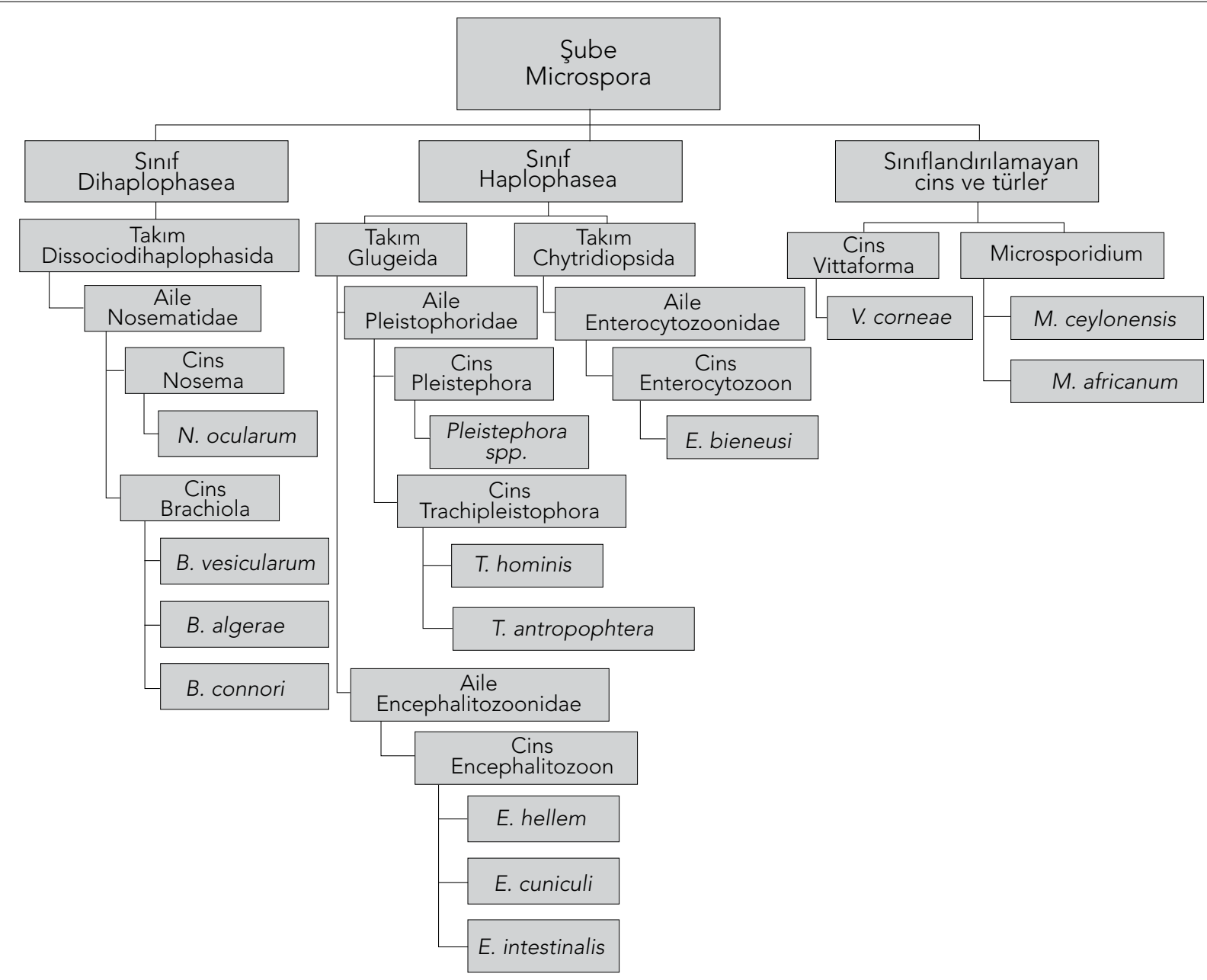


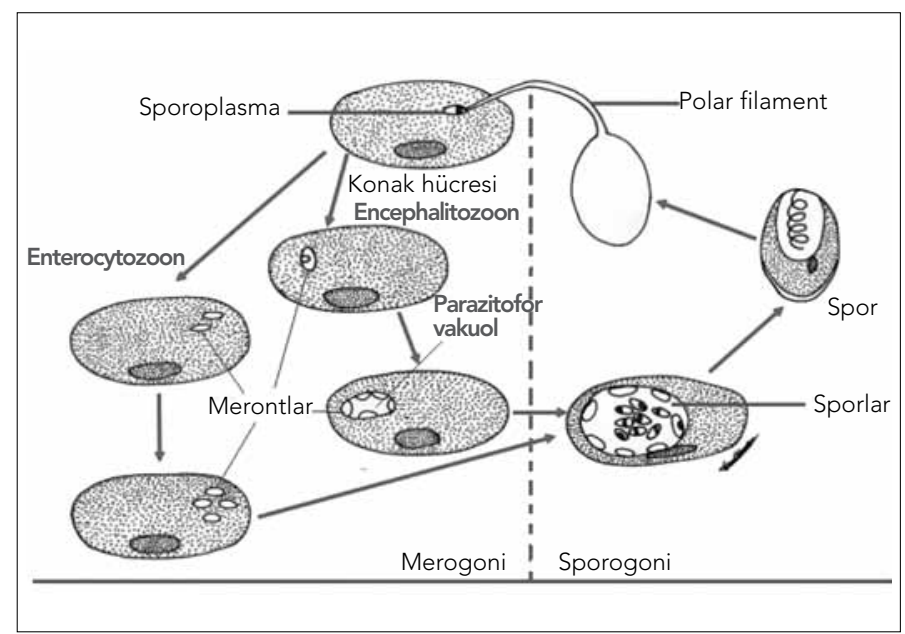

Şekil 3. Spor morfolojisi (Orjinal)

\section{Hayat Döngüsü}

Mikrosporidia türleri, omurgalı ve omurgasız konakları enfekte edebilen zorunlu hücre içi parazitidir. Hatta bu protozoonlar başka parazitlerle aynı hücreyi enfekte edebilmektedirler. Bilinen bir vektör veya ara konakları ve hücre dışında herhangi bir metabolik aktivasyonları yoktur $(11,12)$. Mikrosporidia sporlarının insanlara nasıl bulaştığı hala tam olarak açıklanamamıştır.

Enfektif sporlar; solunum, seksüel yolla (E. hellem), kontamine yiyecekler, su ve direkt temas ile bulaşabilmektedir. Vittaforma, Enterocytozoon ve Encephalitozoon genusu içersinde yeralan türlerin sporlarının su kaynaklı olduğu ve su ile bulaşabileceği belirtilmektedir. Enfekte hayvanlarla direk temas yoluyla hastalığın geçişi önemlidir fakat bu geçiş şekli nadir olarak görülmektedir. Hayvanlarda enfeksiyonun bulaşma şekli olarak transplasental (Encephalitozoon spp.) geçişin olduğu gösterilmiş fakat insanlarda bu yolla enfeksiyonun bulaş şekli henüz gösterilememiştir. Insanları enfekte eden birçok mikrosporidia türünün hayvanları da enfekte edebilmesi zoonotik geçiş olasılığını kuvvetlendirmektedir (12).

Uygun şartlar altında ve uygun konakta bulaşma yoluna bağlı olarak sporların konak hücreye girişiyle enfeksiyon başlamaktadır. Mikrosporidiaların hayatı 3 fazda gerçekleşmektedir (Şekil 3).

1-Faz I- Enfektif /Çevresel faz: Hayatın ekstrasellüler fazıdır. Çevre şartlarına dirençli olan ve uzun süre enfekte kalabilen sporlar direkt temas veya ağız yoluyla alınmaktadır. Sporlar, çeşitli fiziksel ve kimyasal değişiklikler (uygun pH, sıcaklık, nem, iyon konsantrasyonları, sindirim enzimleri, basınç gibi) ve diğer bazı uyaranların etkisiyle konak enterositlerine girer ve burada sporun çimlenmesi aktifleşir. Primer enfeksiyonun lokalizasyonunun bulaş yoluna bağlı olduğu, tipik olarak gastrointestinal ve solunum sistemi epitel hücrelerinde oluştuğu bildirilmektedir. Uygun şartlar altında (uygun $\mathrm{K}^{+}$ve $\mathrm{Ca}^{++}$iyon konsantrasyonunda) spor uygun konak tarafından alındıktan sonra helezon şeklindeki polar tüp düzleşir ve iç içe katlanmış gibi duran bu yapı dışarı doğru uzanır ve konak hücresi içerisine sporoplazma boşaltılması ile hücre enfekte olur. Konak hücre içerisinde, sporlardan serbest kalan sporoplazmalar dış yüzeyleriyle yoğun görünüşü ile tanımlanan sporontları geliştirmek için merontlar oluşur $(5,11,13)$.
2-Faz II- Proliferatif Faz/ Üreme fazı: Mikrosporadiaların hayat döngüsünün bir parçası olan ve intrasellüler gelişmenin gerçekleştiği ilk fazdır. Bu faz, spor şekillenmesine bağlı olarak parazit sporoplazmasının büyüyüp geliştiği ve bölünerek çoğaldığı fazdır. Parazitin gelişimi genus ve aileye göre değişmektedir. Proliferatif faz, merogoni ve sporogoni olmak üzere iki önemli aşamada gerçekleşir. Bu iki aşama da, nükleer kılıfın bozulmadan parazit nükleusunun bölünmesidir (6). Karyokinesiz sonucunda, yuvarlaklaşmış çok çekirdekli plasmodial formlar (E. bieneusi) veya kurdele benzeri çok çekirdekli hücreler ( $E$. intestinalis) oluşur ve bu olay sitokinezisden önce defalarca gerçekleşebilir (11). Sporoplazmanın uygun bir konağa girmesiyle oluşan merontlar, yuvarlak düzensiz veya sitoplazmalarındaki ufak farklılıklarla birlikte yapısal olarak basit ve tek katlı hücre zarına sahip hücrelerdir. Bunlar defalarca ikiye (Encephalitozoon, Nosema, Vittaforma genusu) veya daha fazla sayıya (Enterocytozoon, Pleistophora, Trachipleistophora genusu) bölünerek çoğalırlar ve tek bir hücre içerisinde yaklaşık 50-100 meront oluşur $(6,13)$. Bu merontlar, enterosit, makrofaj, mezenkim hücreleri gibi farklı hücrelerde ve besinleri bu konak hücrelerden absorbe ederek gelişimlerine devam ederler (6). Merontlar, konak hücre sitoplazmasıyla direk temas halinde (Nosema, Enterocytozoon genusu), konak orjinli oluşan parazitoforoz vakuol içinde (Encephlitozoon genusu), parazit tarafından salgılanan sporoforoz vakuol içinde (Pleistophora, Trachipleistophora genusu) veya da konağın endoplazmik retikulumuyla (Endoreticularis, Vittaforma genusu) çevrilerek gelişir (5).

3-Faz III- Sporogonik Faz: Sporların oluşumu organizma aracılığıyla gerçekleşir. Sporogoni, elektronca yoğun bir yüzey örtüsü ve merontların ince bir zarla çevrilerek sporontların oluşumu ile başlar (5). Sporontlar daha sonra olgun sporların plazma membranın dışındaki ekzospor tabakasını oluşturacaklardır (6). Sporontlar, ikiye bölünme ya da çoklu füzyon ile çoğalıp, sporoblastları oluşturur. Oval şekilli sporoblastların olgunlaşmasıyla olgun sporlar meydana gelir (11). Sporlar konak hücresini tamamen doldurduğu zaman plazma membran patlar ve sporlar çevreye dağılır. Bu sporlar ya konak içerisinde yeni bölgelere taşınarak çevredeki diğer hücreleri enfekte edebilir ya da yeni konakları enfekte edebilmek için idrarla veya dışkı ile dışarı atılabilirler (6, $12,13)$.

\section{Mikrosporodiaların Hücreye Giriş Mekanizmaları:}

Sporların enfektif sporoplazmasının hassas bir konağa transferi bir seri kompleks aktiviteler sonucu oluşurken, spor çimlenmesinin aktivasyonu için de çevre şartlarının uygun olması gerekmektedir. Sporun geçirgenliğinde ve polar flamentin ters dönüşünde etkili olan bu çevresel değişiklikler fiziksel veya kimyasal olabilir $(5,14)$. Mikrosporidia enfeksiyonlarının çoğu konağın sindirim sisteminde sporların kimyasal uyaranlarına $(\mathrm{pH}$, sindirim enzimleri, iyon konsantrasyonları vb.) bağlı olarak başlamaktadır (5).

Aktive olan spor, sporoplazmanın kısa zamanda bölünerek yıkılmasına neden olmaktadır. Spor içinde ozmotik basıncın anormal artması posterior vakuolu genişletir ve bu değişim polar tüpün ters dönüşünü tetikler. Sporoplazma, 15-500 ms hızında polar tüpe doğru yönelerek tüple birleşir ve birkaç saniye sonra tüpten ayrılmasıyla hücre invazyonu gerçekleşir. Bu olaylar sporoplazma içerisindeki karbonhidrat oranına ve özellikle de trehaloz enzimi- 
nin aracılık ettiği trehalozun glikoz ve diğer metabolitlere dönüşümüne bağlı olduğu düşünülmektedir $(15,13)$. Mikrosporidialar hücre içerisine deneysel olarak gösterilmiş iki yol ile giriş yapmaktadır;

\section{1-Aktif invazyon:}

Başlangıçta, polar tüp konak hücre plazma membranına penetre olmakta ve hipodermik iğne şeklinde konak hücre sitoplazmasına sporoplazmalarını enjekte etmektedir. Sporoplazmanın polar tüpten lümene doğru geçişi 5-30 sn'de gerçekleşmektedir (6). E. bieneusi polar tüp yardımıyla konak hücre plazma membranını delerek sitoplazma kaybı olmadan hücre içerisine penetre olmaktadır (6). Invazyon süreci sonunda mikrosporidia sporu direkt konak hücrenin sitoplazmasında veya da bir vakuol içinde gelişimine devam etmektedir.

\section{2-Endositosiz:}

Mikrosporidia sporlarının çoğu, polar tüp açılması olmadan internalizasyonla sitoplazmaya girer. Aktin-bağımlı fagositozun aracılık ettiği sporların hücre içersine girişi sitokalazin-D tarafından inhibe edilebilir. Konak hücre tarafından spor endositoz yolu ile hücre içine alınır ve spor fagozomla çevrilir. İçersinde mikrosporidia sporlarını içeren fagozomlar önce endozomal daha sonra lizozomal kompartmanlara dönüşür ve sporlar hızlıca yıkılır fakat bazı sporoplazmaların olgunlaşan lizozomlardan kaçar ve polar tüp salınması yoluyla konak hücre sitoplazmasını enfekte eder (16).

\section{Epidemiyoloji}

Mikrosporidialar bütün dünyada fırsatçı patojenler olarak kabul görmeye başlamış ve Arjantin, Avustralya, Botswana, Brezilya, Kanada, Çek Cumhuriyeti, Fransa, Almanya, Hindistan, İtalya, Japonya, Hollanda, Yeni Zelanda, İspanya, Sri Lanka, İsveç, Isviçre, Uganda, Tayland, Birleşik Krallık, Amerika Birleşik Devletleri ve Zambiya gibi birçok gelişmiş ve gelişmekte olan ülkelerde microsporidiosis vakaları bildirilmiştir (1).

Ülkemizde yapılan sınırlı sayıdaki araştırmada Karaman (11) değişik hasta gruplarından oluşan 2665 kişinin \%8.5'inde; Atambay ve arkadaşları (17) immün sistemi sağlam ve sindirim sistemi yakınmaları nedeni ile hastaneye başvuran 781 kişinin \%6,5'inde; Karaman ve arkadaşları (18), kanser tanısı almış 320 kişinin \%10,9'ında ve sağlıklı bireylerden oluşan 320 kişilik kontrol grubunun \%5,6'sında; Türk (19) ishal şikayeti olan 225 hastanın \%9,8'inde; Yazar ve arkadaşları (20) kanserli bir hastada, Büget ve arkadaşları (21) ise bir AIDS hastasında Microsporidia spp. bildirmişlerdir.

\section{Mikrosporidialarda Tanı Yöntemleri}

Tanı için dışkı ya da duodenal drenaj örnekleri taze materyal şeklinde veya \%5-10 formolde laboratuvara gönderilebilir. Ayrıca taze dokular serum fizyolojik içinde ya da antibiyotikli besiyeri içinde saklanabilir. Fakat hücre kültürü ya da moleküler inceleme için taze materyalin olması gerekmektedir. Sistemik enfeksiyonlarda örnek olarak idrarın kullanılması önerilmektedir. Yine diğer vücut sıvıları (balgam, bronkoalveolar lavaj, nazal akıntı veya beyin omurilik sıvısı) konjunktiva sürüntüsü, kornea kazıntısı veya doku örneği de incelenebilir $(1,22)$. Kas ve karaciğer gibi biyopsi örnekleriyle tanı konulabilirse de, biyopsi örneği için en uygun bölge ince bağırsaklardır (23). Kronik ishalli ve CD4+ sayısı 100 $\mathrm{mm}^{3}$ 'ün altındaki hastalarda mikrosporidial enfeksiyonların öncelikle düşünülmesi ve araştırılması önerilmektedir (23).

\section{Dışkı örneklerinin ışık ve fluoresan mikroskobu ile incelenmesi}

Işık mikroskobu tanıda etkili olmasına karşın cins ve tür düzeyinde ayırım yapılmasını sağlamamaktadır. Mikrosporidialar, hücre içinde veya dışında oval reflektif cisimcikler olarak görülebilirler. Gram boyama ile gram pozitif boyanan parazit sporları maya hücrelerine benzer bir görünüm sergilerler. Ancak pembemsikırmızı renkte boyanması ve tomurcuklanma göstermemesi ile mayalardan ayrılırlar. Kesin ayırım için \%1'lik aside dirençli boyama ya da Weber'in modifiye trikrom boyama yöntemi ile tanının doğrulanması gerekmektedir $(4,24,25)$.

\section{a) Modifiye Trikrom Boyası (Weber'in Trikrom Boyası, Kromotrop 2R boyası)}

Bu boya ile boyanan preparatlar ışık mikroskobunda incelendiğinde; mikrosporidia spor duvarı parlak pembe renge boyanırken (Resim 1), E. bieneusi 0,8 ila 1,4 $\mu \mathrm{m}$, B. algerae, Encephalitozoon spp., V. corneae ve Nosema spp. türleri 1.5-4 $\mu \mathrm{m}$ boyutlarında görülmektedir $(4,26)$. Araştırmacılar, bu yöntemin mikrosporidiaların rutin tanısında kullanılabileceğini bildirmişlerdir (27).

Ryan ve arkadaşları (28) bu boyama yönteminin bir basamağında kullanılan fast green yerine aniline blue kullanmışlar ve bu yöntem ile parazitlerin daha iyi boyandığını bildirmişlerdir (Resim 2A, B).

\section{b) Fluoresans boyalar}

Mikroporidia sporlarının boyanması için kullanılan başlıca fluoresan boyalar, kalkoflor beyazı, Fungi flor ve Uvitex 2B'dir. Bu boyalardan Uvitex 2B ve kalkoflor beyazı spor duvarı endospor tabakasındaki kitine bağlanarak mavi-beyaz fluoresans verir. Kitin içeren diğer mikroorganizmalar, özellikle de mantar sporları bu boyalar ile boyandıklarından dolayı ayırıcı tanı önemlidir (29). Tuli ve arkadaşları (30) mikrosporidiaların teşhisinde 4,6 diamidin-2- fenilindol (DAPI) ve kalkoflor beyazı boyasının birlikte kullanıldığı bir yöntemin, spesifitesini \%97, sensitivitesini ise \%98.5 olarak saptamışlardır. Miller ve Smekova (31) isimli araştırmacılar ise oolong tea extract (OTE) boyasının tanıda başarılı bir şekilde kullanılabileceğini göstermişlerdir.

Araştırmacılar tanıda fluoresan boyaların kullanılmasının hızlı ve kolay olması nedeniyle avantajlarının olduğunu ayrıca MTS ile paralel boyanmasının da tanıda duyarlılığın arttığını bildirmişler$\operatorname{dir}(32,33)($ Resim 3).

Diğer taraftan mikrosporidiaların canlılık testi, için kalkoflor M2R ve Sytox green boyaları kullanılabilmektedir. Canlı sporlar kalkoflor M2R boyası ile 395-415 nm dalga boyunda turkuaz-mavisi renkte oval şekilli görülürken ölü sporlar beyaz-sarı renkte gözlenmektedir. Sytox green ile boyamada ise canlı sporlar görüntü vermezken ölü sporların içerisine boya rahatlıkla girebilmekte ve 470-490nm dalga boyunda parlak sarı-yeşil renkte fluoresans vermektedir (34).

\section{c) Warthin-Starry (WS) boyası}

Bu boyama yöntemi E. bieneusi ve Encephalitozoon türlerinin tanısında kullanılabilen ve duyarlılığı oldukça yüksek bir tanı yöntemidir. Bu yöntem sonuçlarının elektron mikroskobu (EM) sonuçlarıyla \%100 uyum gösterdiği tespit edilmiştir (35). 


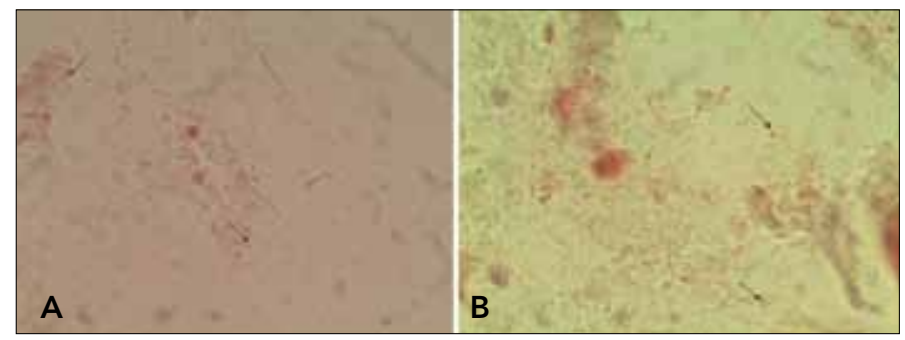

Resim 1. Mikrosporidia sporlarının modifiye trikrom boyama ile 1000X büyütmedeki görüntüsü (Orjinal)

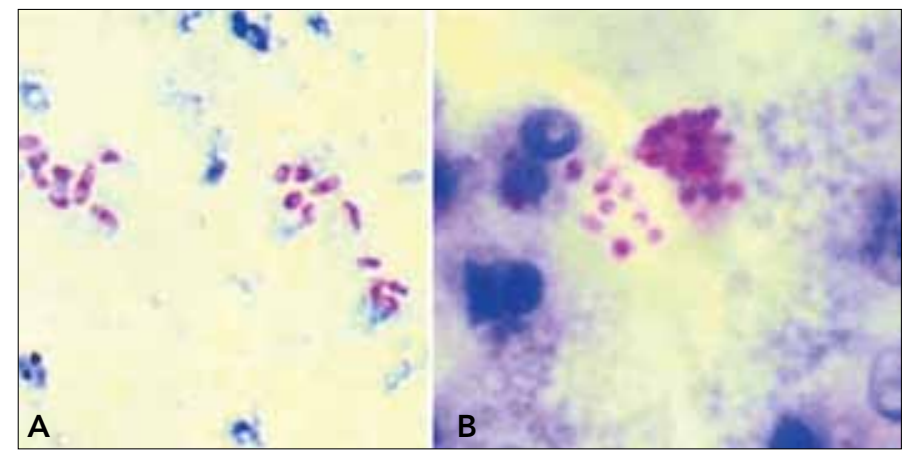

Resim 2A, B. Mikrosporidia sporlarının modifiye trikrom boyama yönteminde fast gren yerine aniline blue kullanılması ve 1000X büyütmedeki görüntüsü (25)
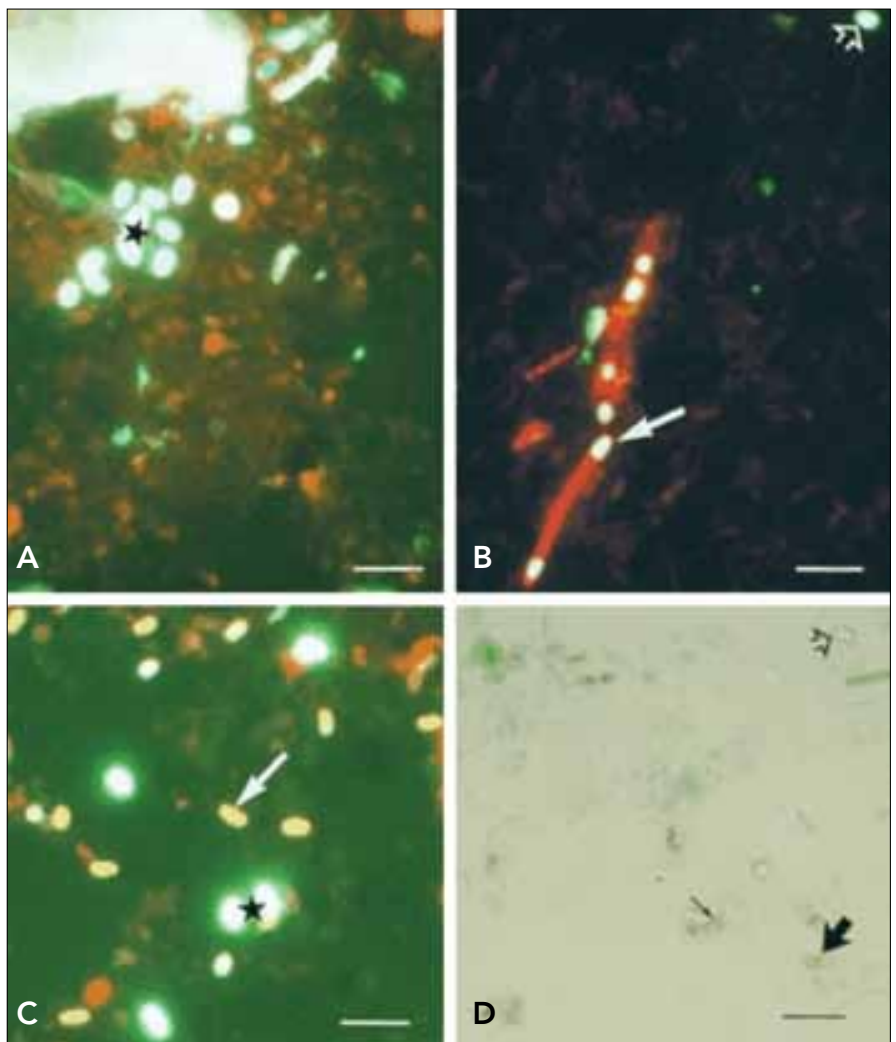

Resim 3. Calcofluor ve MTS ile boyanan sporlar

A: ( $\star$, mavimsi parlak görülenler kalkoflor beyazı ile boyanmış sporlar

B: $(\leadsto)$ tek olan spor, $(\rightarrow)$ kırmızı boyanmış olanların içinde olanlar bakteri

C: $(\star)$ sporlar $(\rightarrow)$ sarımsı boyananlarda sporlar

D: MTS ile boyanmış boş spor $(\hookrightarrow),(\rightarrow)$ ve $(\rightarrow)$ normal sporlar $(31,32)$.

\section{Histolojik Incelemeler}

Sürüntülerde Uvitex 2B veya kalkoflor beyazı boyama yöntemi, kesitlerde ise kalkoflor beyazı boyama yöntemi, modifiye trikrom boyama yöntemi, Giemsa boyama yöntemi, Masson'nun trikrom boyama yöntemi, akridin oranj, Gomori'nin methenamin gümüş boyama yönteminin kullanılabileceği araştırmacılar tarafından belirtilmektedir (24).

\section{Serolojik tanı}

Mikrosporidiaların tanısında enzim bağlı immünosorbent yöntemi (ELISA), Western Blot, indirekt fluoresan antikor testi (IFAT), immün fluoresan ve immünoperoksidaz yöntemlerinin kullanılabileceği bildirilmiştir $(24,29)$.

Seroepidemiyolojik çalışmalarda kullanılan bu testler ile mikrosporidialara karşı tespit edilen antikorların, yeni bir enfeksiyon, latent bir enfeksiyon, çapraz reaksiyon veya poliklonal B hücre aktivasyon olup olmadığının gösterilmesinde güçlükler bulunduğu belirtilmiştir (36). Yapılan bir çalışmada, E. bieneusi'nin tanısında monoklonal antikor testinin polimeraz zincir reaksiyonu (PZR) ve IFAT'a göre daha duyarlı olduğu gösterilmiştir (37). Monoklonal antikorların kullanıldığı immunofluoresan antikor testleri ile dışkıda E. intestinalis ve E. bieneusi'e ait sporlar belirlenebilmektedir. Bu yöntemin duyarlılı̆ı \%100'e yakın, özgüllüğü ise bilinen diğer yöntemlerden daha yüksektir. Monoklonal antikorlar örnekte bulunan sporların spor duvarındaki proteinlere bağlanmakta ve fluoresan mikroskobunda sporlar parlak yeşil röfle vermektedir (Resim 4, 5).

\section{Flow sitometri yöntemi}

Flow sitometri (FCM) kullanılarak mikrosporidiaların tanısı yapılabilmektedir (38). Franzen ve arkadaşları (38) kültürü yapılmış olan mikrosporidiaları FCM yöntemi ile tespit etmişler ve bu yöntemin kullanım kolaylığı ve yüksek bir duyarlılığa sahip olması nedeniyle araştırmalarda kullanılabileceğini vurgulamışlardır.

\section{Transmisyon Elektron Mikroskobu (TEM)}

Mikrosporidiaların tanısında TEM yönteminin, özgüllüğü yüksek olup duyarlılığı düşüktür. Ayrıca yorucu ve uzun zaman gerektirmektedir. TEM ile parazitin polar filamenti tespit edilebilmektedir. Günümüzde TEM, moleküler yöntemlerin uygulanmadığı laboratuvarlarda halen tanımlamada kullanılan ve tür tayininde altın standart kabul edilen bir yöntemdir (22). TEM ile sporların yapısal özellikleri incelenerek, parazitin cins ve tür düzeyinde ayrımı yapılabilmektedir. Ancak E. cuniculi ve E. hellem'in TEM ile tanısı oldukça zordur $(22,24)$.

\section{Hücre Kültürü}

Insanları enfekte eden türlerin hepsi olmasa da bir kısmının kültürleri yapılabilmiştir (N. corneum, E.hellem, E.cuniculi, E.intestinalis, T. hominis ve V. corneae) (22). Ancak E. bieneusi'nin uzun süreli kültürü yapılamamaktadır (39).

\section{Mikrosporidiaların Tanısında Moleküler Yöntemler}

Rutin klinik laboratuvarlarında mikrosporidiaların tanısı amacıyla halen mikroskopi temelli yöntemler uygulanmasına rağmen son on yıldır araştırma laboratuvarlarında teşhis amacıyla moleküler yöntemlerin kullanılması ivme kazanmıştır. Moleküler yöntemlerin başarısı, klinik örneklerden nükleik asitlerin ekstraksiyonu için kullanılan yöntemlerle çok yakından ilişkilidir (40). 


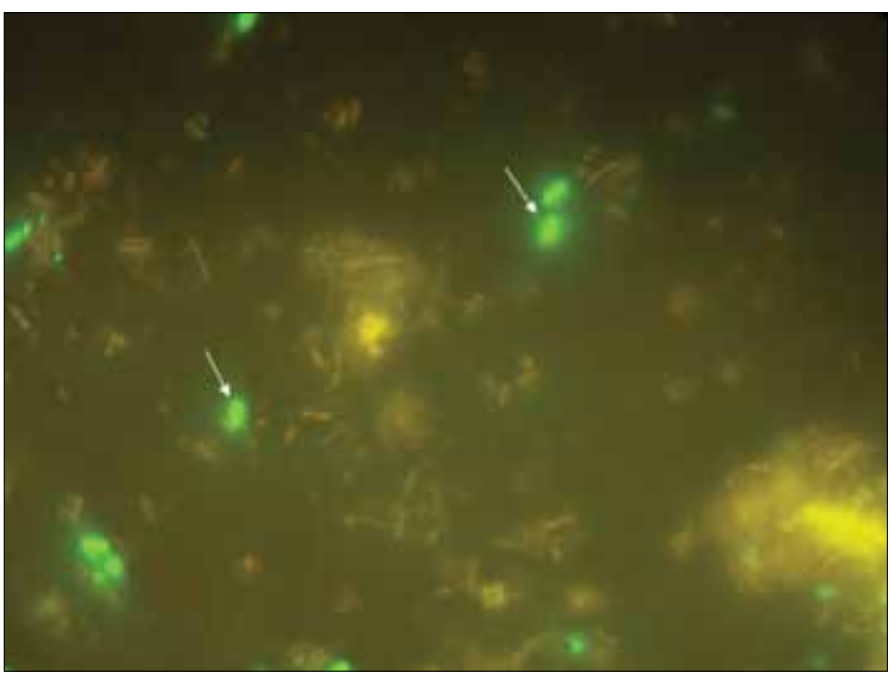

Resim 4. E.intestinalis sporlarının immunofluoresan antikor yöntemi ile fluoresan mikroskobunda x1000 büyütme ve 450-490 nm'deki görüntüsü (Orjinal)

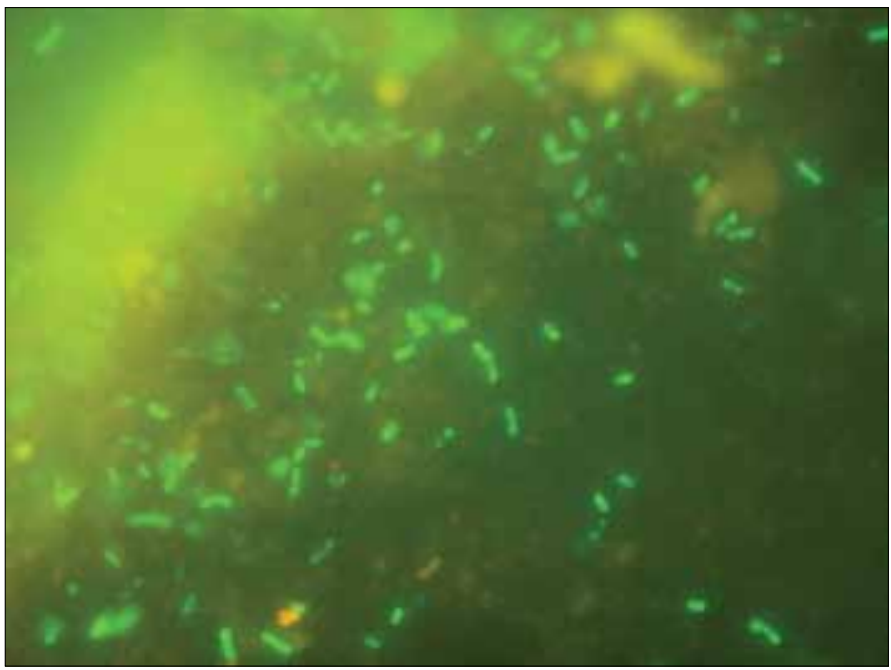

Resim 5. E.bienusi sporlarının immunofluoresan antikor yöntemi ile fluoresan mikroskobunda x1000 büyütme ve 450-490 nm'deki görüntüsü (Orjinal)

Mikrosporidiaların moleküler teşhisi amacıyla doku biopsileri, korneal kazıntı örnekleri, düodenal aspiratlar, idrar örnekleri ve in-vitro kültür örnekleri kullanılabilir (1).

Bu örneklerden nükleik asit ekstraksiyonu için ticari kitler (Qiagen (Santa Clara, Calif, ABD) veya Promega (Madison, Wis, ABD) kullanılabildiği gibi klasik ekstraksiyon yöntemi olan fenol-kloroform ve etil alkol presipitasyon yöntemi de uygulanabilir. Ayrıca formalinle fiske edilmiş parafine gömülmüş biyopsi örneklerinden DNA ekstraksiyonu için ticari kitler bulunmaktadır (DexPAT, Takera Biochemical, Berkeley, Calif, ABD) (40).

Genellikle dışkıdan DNA izolasyonu oldukça zordur ve değişkenlik göstermektedir. Mekanik olarak sporların parçalanmasına ve daha zor bir ekstraksiyon şartlarına gerek duyulmaktadır. Başarılı bir ekstraksiyon için \%0,5 sodyum hipoklorit, kitinaz, litikaz, guanidin tiyosiyanat, \%10 formaldehit veya $1 \mathrm{M}$ potasyum hidroksit, dithiotreitol, hekzadeksiltrimetilamonyum bromit kullanımı veya örneklerin kaynatılması ile ilgili çalışmalar bulunmaktadır. Dışkının moleküler yöntemler içersinde kullanımının diğer bir zorluğu sıklıkla polimeraz enzim inhibitörleri içermesinden dolayıdır. Inhibitörlerin uzaklaştırılması için basit olarak örneklerin dilüsyonu veya guanidin tiyosiyanat ile muamele çeşitli otörler tarafından tavsiye edilmektedir $(40,41)$. Bunlardan başka denatürantların, şelat yapıcı ajanların ve serbest radikal bağlayıcıların emdirilmiş olduğu FTA filtre metodununda mikrosporidia sporlarının ekstraksiyonu için oldukça etkili olduğu belirtilmektedir (42).

Ökaryotik organizmalarla karşılaştırıldığında mikrosporidialar oldukça küçük genoma sahiptir. Değişken alanlı jel elektroforezi (Pulsed-field gel electrophoresis) çalışmaları haploid genom boyutlarının ortalama 5,3 ile 19,5 Mb arasında olduğunu göstermiştir. Mikrosporidia rRNA gen bölgesi, genler arası transkripsiyonu yapılmayan ara bölge ile ayrılan 16S SSU rRNA ve 23S LSU rRNA genlerinden oluşmaktadır. Mikrosporidiaların PCR temelli teşhisinde bu gen bölgelerinden (SSU rRNA, LSU rRNA, $\alpha$ ve $\beta$-tubulin, polar tube protein, polar tube protein 55 precursor, ribosomal protein $\mathrm{L} 27 \mathrm{a}$, dihydrofolate reductase, serine hydrxymethyltransferase, aminopeptidase, thymidylate synthase, internal transcribed spacer ve actin gen bölgesi) hazırlanmış primerler kullanımaktadır (1). Mikrosporidia GenBank sekans verilerinin (yaklaşık 6000) çoğunluğu korunmuş ve değişken bölgeler içeren rRNA genlerine aittir (40). Bundan dolayı mikrosporidiaların teşhisi amacıyla kullanılan PCR temelli yöntemlerinde bu gen bölgelerinden hazırlanan primerler çoğunlukla tercih edilmektedir. Insanlarda sıklıkla enfeksiyon oluşturan beş mikrosporidia türünün (E. bieneusi, E. intestinalis, E. cuniculi, E. hellem ve $V$. cornea) ve diğer mikrosporidiaların tanısında SSU rRNA hedef gen bölgesinden hazırlanmış tür spesifik ve jenerik primer çiftleri başarıyla kullanılmaktadır (1).

Aynı şekilde E. bieneusi ve Encephalitozoon spp. tanısı amacıyla rRNA bölgesinden hazırlanan primer ve probların kullanıldığı multipleks real-time PCR yönteminin \%100 sensitivite ve spesifiteye sahip olduğuna dair yayınlar bulunmaktadır. Bu yöntemin dışkıda $10^{2}$ spor/mL saptayabilme duyarlılığına sahip olduğu bildirilmektedir $(40,41)$.

Ayrıca mikrosporidia türlerinin tanısında $16 \mathrm{~S}$ rRNA gen bölgesi hedef alınarak tasarlanmış fluoresan işaretli probların örnek içersindeki uygun nükleik asit dizisine bağlanması esasına dayalı in situ hibridizasyon (FISH) temelli tekniklerde moleküler tanıda kullanılmaktadır. Mikrosporidiaların dört türüne ( $E$. bieneusi, $E$. intestinalis,, E. cuniculi, ve E. hellem) özgü hazırlanmış oligonükleotit problarla yapılan bir multipleks fluoresan in situ hibridizasyon çalışmasında, sporları boyamaya yönelik kromotrop-2R ve kalkoflor beyazı M2R boyalarının kullanıldığı mikroskopik tanıya göre daha duyarlı olduğu gösterilmiştir (43). Formalinle sabitlenmiş, parafine gömülmüş klinik örneklerden mikrosporidiaların teşhisinde rutinde kullanılan histokimyasal boyalara göre daha başarılı olduğu gösterilmesine rağmen birçok aşamasının olması, prob hibridizasyonu için bir gece beklenmesi, epi-fluoresan bir mikroskop gerektirmesi, duyarlılığının PCR'dan daha düşük olması bu tekniğin rutin kullanımını kısıtlamaktadır (40).

Son zamanlarda popüler olan mikroarray teknolojisi mikrosporidiaların tanısı amaçlı geliştirilmiştir. Wang ve arkadaşları insanda en sık enfeksiyon oluşturan dört türe karşı spesifik oligonükleotit- 
ler kullanarak bu yöntemin aynı anda dört türü ve miks enfeksiyonları yüksek bir duyarlılıkta (10²spor/100ul dışkı örneği) saptayabileceğini göstermişlerdir. Oldukça pahalı bir teknik olması ve gelişmiş bir merkez gerektirmesinden dolayı şuan rutin kullanıma geçmesi uzak görülmektedir (44).

Mikrosporidiaların filogenetik analizinde ITS (Internal Transcribed Spacer) gen bölgesine göre hazırlanmış primerlere dayalı DNA sekans analizleri sıklıkla kullanılmaktadır. Insan ve hayvanlardan izole edilen E. bieneusi'nin ITS gen bölgesi sekans analizleri sonucu olarak 70'den fazla genotip olduğu gösterilmiştir. Bu genotipler içersinde genotip $A$ ve $B$ genellikle antroponotik potansiyele sahipken, genotip K (ayn zamanda genotip IV, BEB5 ve Peru2), D ve E zoonotik potansiyele sahiptir. Genotiplendirme analizleri yapılarak zoonotik ve antroponotik geçişin gösterilmesi, enfeksiyonun sıklıkla görüldüğü bölgelerde kontrol stratejilerinin belirlenmesi açısından büyük önem arzetmektedir $(45,46)$. Tanıda kullanılan tür-spesifik primer çiftleri Tablo 2'de sunulmuştur (46-55).

Sonuç olarak duyarlılığının, özgüllüğünün yüksek olması, hızlı ve doğru sonuç verme ve tedavi açısından önemli olan aynı anda birden fazla türün tespitine olanak sağlama açısından bakıldığında, moleküler yöntemler mikrosporidiaların tanısına değer kazandırmaktadır.

\section{KLINIK}

Mikrosporidialar genellikle HIV pozitif, organ transplant alıcıları, kanserli hastalar gibi immun yetmezlikli bireyler ile çocuklar, turistler, kontakt lens kullananlar ve yaşlılarda fırsatçı enfeksiyonlara neden olmaktadır $(1,6)$. Klinik semptomlar, enfeksiyonun lokalizasyonu ve konağın immün durumu ile yakından ilişkilidir (9). Insana yerleşen mikrosporidia türleri ve bunlara bağlı olarak oluşan klinik bulgular Tablo 3'te özetlenmiştir. $(1,6)$.

\section{Gastrointestinal Tutulum}

Sindirim sistemi enfeksiyonlarında en sık izole edilen türler E. bieneusi, E. intestinalis ve E. cuniculi olarak bildirilmektedir (7, 57). Mikrosporidia kaynaklı intestinal enfeksiyonlar AIDS'li kişilerde sık görülen bir durumdur ve enfeksiyonların çoğunda etken E.bieneusi'dir. En belirgin semptomları kronik ishal, anoreksi ve kilo kaybı şeklinde gözlenmektedir (1). Encephalitozoon türlerinin klinik belirtileri E. bieneusi'ye benzer şekilde ishal, kilo kaybı ve malabsorbsiyondur (1).

\section{Oküler Tutulum}

Oküler mikrosporidiosis keratokonjonktivit ve stromal keratit olmak üzere iki klinik tablo şeklinde karşımıza çıkmaktadır $(6,8)$. Keratokonjonktivit form: Genellikle immün yetmezlikli hastalarda ve kontakt lens kullanıcılarında görülmektedir. Etken sıklıkla Encephalitozoon türleridir. Enfeksiyon gözde yabancı cisim hissi,

Tablo 2. Mikrosporidiaların tanısında kullanılan tür-spesifik primer çiftleri

\begin{tabular}{|c|c|c|c|}
\hline Amplifiye olan tür & Primer çifti sekansı $\left(5^{\prime}-3^{\prime}\right)$ & Primer ismi & Referans \\
\hline E. bieneusi & $\begin{array}{l}\text { GAA ACT TGT CCA CTC CTT ACG } \\
\text { CCA TGC ACC ACT CCT GCC ATT }\end{array}$ & $\begin{array}{l}\text { EBIEF1 } \\
\text { EBIER1 }\end{array}$ & 46 \\
\hline E. bieneusi & $\begin{array}{l}\text { CAC CAG GTT GAT TCT GCC TGA C } \\
\text { ACT CAG GTG TTA TAC TCA CGT C }\end{array}$ & $\begin{array}{c}\text { V1 } \\
\text { EB450 }\end{array}$ & 47 \\
\hline E. bieneusi & $\begin{array}{l}\text { CAC CAG GTT GAT TCT GCC TGA C } \\
\text { CAG CAT CCA CCA TAG ACA C }\end{array}$ & $\begin{array}{c}\mathrm{V} 1 \\
\mathrm{Mic3}\end{array}$ & 48 \\
\hline E. bieneusi & $\begin{array}{l}\text { TCA GTT TTG GGT GTG GTA TCG G } \\
\text { GCT ACC CAT ACA CAC ATC ATT C }\end{array}$ & $\begin{array}{l}\text { Eb.gc } \\
\text { Eb.gt }\end{array}$ & 49 \\
\hline E. bieneusi & $\begin{array}{l}\text { GCC TGA CGT AGA TGC TAG TC } \\
\text { ATG GTT CTC CAA CTG AAA CC }\end{array}$ & $\begin{array}{l}2 \\
2\end{array}$ & 50 \\
\hline E. intestinalis & $\begin{array}{c}\text { CAC CAG GTT GAT TCT GCC TGA C } \\
\text { CTC GCT CCT TTA CAC TCG AA }\end{array}$ & $\begin{array}{l}\mathrm{V} 1 \\
\mathrm{SI} 1500\end{array}$ & 51 \\
\hline E. intestinalis & $\begin{array}{l}\text { TTT CGA GTG TAA AGG AGT CGA } \\
\text { CCG TCC TCG TTC TCC TGC }\end{array}$ & $\begin{array}{l}\text { SINTF1 } \\
\text { SINTR }\end{array}$ & 52 \\
\hline E. intestinalis & $\begin{array}{l}\text { GGG GGT AGG AGT GTT TTT G } \\
\text { CAG CAG GCT CCC TCG CCA TC }\end{array}$ & $\begin{array}{l}3 \\
3\end{array}$ & 50 \\
\hline E. hellem & $\begin{array}{l}\text { TGA GAA GTA AGA TGT TTA GCA } \\
\text { GTA AAA ACA CTC TCA CAC TCA }\end{array}$ & $\begin{array}{l}\text { EHEL-F } \\
\text { EHEL-R }\end{array}$ & 53 \\
\hline E. cuniculi & $\begin{array}{l}\text { ATG AGA AGT GAT GTG GTG TGC G } \\
\text { TGC CAT GCA CTC ACA GGC ATC }\end{array}$ & $\begin{array}{l}\text { ECUN-F } \\
\text { ECUN-R }\end{array}$ & 53 \\
\hline V. cornea & $\begin{array}{l}\text { TGA GAC GTG AAG ATG AGT ATC } \\
\text { TCC CTG CCC ACT GTC TCC AAT }\end{array}$ & $\begin{array}{l}\text { NCORF1 } \\
\text { NCORR1 }\end{array}$ & $\begin{array}{c}\text { CDC'den Norman } \\
\text { Pieniazek'e ait } \\
\text { (yayınlanmamış) }\end{array}$ \\
\hline $\begin{array}{l}\text { Anncaliia (Brachiola) } \\
\text { algerae }\end{array}$ & $\begin{array}{l}\text { ACT CCG GTA ACG TGT GAT GTG } \\
\text { TAC AAA GCA TGA TCC CAG TCT }\end{array}$ & $\begin{array}{l}\text { NALGf2 } \\
\text { NALGR1 }\end{array}$ & 54 \\
\hline $\begin{array}{l}\text { Anncaliia (Brachiola) } \\
\text { algerae }\end{array}$ & $\begin{array}{c}\text { GCC GTT TCC GAA GTT GG } \\
\text { ATA TCG ACG GGA CTC TCA CC }\end{array}$ & $\begin{array}{l}\text { NAGf } \\
\text { NAG178r }\end{array}$ & 55 \\
\hline
\end{tabular}


Tablo 3. Insana yerleşen mikrosporidia türleri ve bunlara bağlı olarak oluşan klinik bulgular

\begin{tabular}{|l|l|}
\hline Türler & Klinik Bulgular \\
\hline E bieneusi & Enterit, diyare, kolanjit, kolesistit, pnomoni, bronşit, sinuzit, rinit \\
\hline E. intestinalis & $\begin{array}{l}\text { Enterit, diyare, ince bağırsak perforasyonu, kolanjit, kolesistit, nefrit, bronşit, sinuzit, rinit, } \\
\text { keratokonjonktivit, dissemine enfeksiyon }\end{array}$ \\
\hline E. hellem & Sinuzit, rinit, keratokonjonktivit, dissemine enfeksiyon, nefrit, üretrit, prostatit, üreterit, sistit, pnomoni \\
\hline E.cuniculi & $\begin{array}{l}\text { Sinuzit, rinit, keratokonjonktivit, dissemine enfeksiyon, hepatit, peritonit, ensefalit, intestinal enfeksiyon, } \\
\text { üriner sistem enfeksiyonları }\end{array}$ \\
\hline T. hominis & Miyozit, sinuzit, rinit, keratokonjonktivit \\
\hline T. anthropophthera & Ensefalit, miyozit, dissemine enfeksiyon \\
\hline Pleistophora spp. & Miyozit \\
\hline V. corneae & Keratit, üriner enfeksiyonlar \\
\hline N. ocularum & Keratokonjonktivit \\
\hline B. connori & Dissemine enfeksiyon \\
\hline B. vesicularum & Miyozit \\
\hline B. algerae & Keratokonjonktivit \\
\hline M. africanum & Korneal ülser \\
\hline M. ceylonensis & Korneal ülser \\
\hline
\end{tabular}

aşırı gözyaşı, göz ağrısı, azalan görme keskinliği ve fotofobi gibi klinik belirtiler göstermektedir $(6,8)$. Stromal keratit form: Daha çok immün sağlıklı bireylerde görülmekte olup etken genellikle Nosema ve Microsporidium türleridir. Sinsice başlar ve rekürren stromal infiltrasyon ve üveitin geliştiği progresif herpes diskiform keratitini taklit eder $(6,8)$.

\section{Hepatobiliyer Tutulum}

Etken genellikle Encephalitozoon türleridir. Illk olarak, hepatit gelişen iki AIDS'li hastanın otopsileri sonrasında etken olarak bildirilmiştir. Bunun yanında birçok HIV pozitif hastanın nonparankimal karaciğer hücrelerinde, E. bieneusi ve $E$. intestinalis tespit edilmiş fakat hastalarda tipik hepatit klinik bulguları oluşturmamıştır (7, 11). Mikrosporidialar AIDS'li hastalarda kolanjite neden olan etkenler arasında nadir olarak görülmektedir. Fakat son zamanlarda bu kanı mikrosporidialar için gelişen tanı yöntemlerine bağlı olarak değişmeye başlamıştır.

\section{Sistemik Mikrosporidia Enfeksiyonları}

Insanda enfeksiyon oluşturan üç Encephalitozoon türü sistemik enfeksiyonlara yol açabilmektedir. Trachipleistophora, Pleistephora ve Brachiola genusunda bazı türlerinde sistemik enfeksiyonlara yol açabildiği bildirilmektedir. Bu türlerin oluşturduğu enfeksiyonlar özellikle CD4+ hücre sayısı <50 hücre/ $\mu \mathrm{L}$ olan şiddetli immun yetmezlikli hastalarda sistemik enfeksiyonlara dönüşme eğilimindedir. E. bieneusi tarafından oluşturulan enfeksiyonlar ise genellikle bağırsak epitel hücrelerinde ve hepatobiliyer bölgede sınırlanmıştır (1).

\section{Nadir Görülen Diğer Mikrsoporidia Enfeksiyonları}

Mikrosporidia türlerinin ayrıca serebral tutuluma, pulmoner enfeksiyonlara, üriner enfeksiyonlara, sinüzit, miyozit, peritonit, pankreatit, prostatit, dil ülserleri, kemik ve deri tutulumuna da neden olduğu bildirilmiştir $(1,6,7)$.

\section{Immünite}

Mikrosporidiosise bağlı immün yanıt, konak ve parazitin türüne göre oluşmaktadır (19). Immunocompetent bireylerde mikrosporidia'ya karşı IgM ve IgG antikorları gelişmekte ve yaşam boyu devam etmektedir. Immunsupresif bireylerde ise antikor yanıtı değişkendir $(15,58)$.

AIDS ve organ transplantasyonu olan immünsupresif bireyler, mikrosporidiosise oldukça duyarlı olup özellikle bu tür hastalarda hücresel bağışıklık, mikrosporidiosis'den korunmada önemli bir faktördür. $\mathrm{CD}^{+}$ve $\mathrm{CD}^{+}$hücreleri enfeksiyona karşı dirençte önemli olup, CD8 ${ }^{+} \mathrm{T}$ hücreleri hücre içi enfeksiyonlarda önemli rol oynamakta ve parazit replikasyonunu kontrol etmektedir. E. cuniculi enfeksiyonlarında $\mathrm{CD}^{+} \mathrm{T}$ lenfositlerinin konağın korunmasında ve uzun süreli bir immün yanıtın oluşmasında önemli rol oynadığı bildirilmektdir (58).

Farelerde yapılan çalışmalarda IFN- $\alpha$ ve IL-12 eksikliğinin yüksek bir mortaliteye sahip olduğu bu nedenle, immün yanıtın oluşmasında önemli olduğu bildirilmiştir. IL-12, hücresel immun yanıtın başlaması ve düzenlenmesinde rol oynayan önemli bir regülatör sitokindir. IL-12 yokluğunda Th2 yanıtın Th1 sitokinlere bağlı olarak herhangi bir inhibisyon yokken antikor üretiminin azaldığı belirtilmektedir (15).

\section{TEDAVi}

Mikrosporidial enfeksiyonların tedavisi intrasellüler olmaları ve sporlarının doğal direnci nedeniyle oldukça zordur. İnsanda görülen mikrosporidia enfeksiyonlarının çoğu enteriktir. Genellikle E. bieneusi'nin E. intestinalis'ten daha yaygın olduğu fakat E. intestinalis'in tedaviye daha fazla duyarlı olduğu belirtilmektedir (6). Mikrosporidia tedavisinde genel olarak, albendazol, fumagillin, metronidazol, Itrakonazol, trimetoprim-sulfametoksazol (TMP-SMX), atovakuon, furazolidon, nitazoksanid gibi ilaçlar kullanılmaktadır. 
HIV ile enfekte hastalarda, özellikle E. intestinalis ve E. bieneusi'nin etken olduğu gastrointestinal tutulumlarda hastalığın progresif, sıklıkla fatal ve tedavisinin imkansız olduğu düşünülürken albendazol kullanımı ile mikrosporidiozis insidansında belirgin bir azalmanın olduğu belirtilmektedir. Benzimidazol türevi olan ve tubulinlere bağlanıp hücresel bölünmeyi durdurarak etki gösteren albendazol, günümüzde tedavide en çok ümit veren anti-mikrosporidial ajan olarak kabul edilmektedir $(6,7)$.

Fumagillin (3×20 mg/gün) veya TNP-470'in E. bieneusi enfeksiyonlarındaki hastaların tedavisinde daha etkili olduğu belirtilmektedir $(59,60)$. Fumagillin, başta Entamoeba histolytica olmak üzere in-vitro amoebisidal etkinliğinin olduğu belirtilirken son zamanlarda ilacın anti-mikrosporidial etkinliğinin de olduğu saptanmış ve tedavide kullanılmaya başlanmıştır. Prufiye fumagillin insanlar için toksik olduğu belirtilmesine rağmen, E. bieneusi ile enfekte dört hastaya uygulanmış ve bu hastaların tedavi edildiği, fakat ilaç tedavisi yarıda bırakıldığı zaman trombositopeniye neden olduğu belirtilmektedir (6)

Anti-mikrosporidial aktivitesine sahip olan talidomidin tümör nekrosiz faktörünü düşürdüğü göz önüne alınarak, enterik mikrosporidial enfeksiyonu süresince diyaresi olan HIV pozitif hastalarda etkili olabileceği bildirilmiştir. Özellikle E. bieneusi'ye bağlı enfeksiyonlara karşı tedavide kullanılması önerilmiştir (6).

E. cuniculi ile enfekte hücre kültürleri üzerinde albendazolün direkt etkisi çalışılmış, parazitin proliferatif dönemlerinin geliştiği fakat çekirdeklerinin olmadığı görülmüştür. Bunun nedeninin albendazolün mikrotübüllerin polimerizasyonu durdurması olduğu rapor edilmektedir (60).

E. bieneusi'nin aksine, E. intestinalis'in albendazol ile yapılan tedaviye daha duyarlı olduğu görülmüştür. E. bieneusi konak hücre sitoplazmasında direkt olarak çoğalmasına rağmen, bir parazitoforoz vakuol içerisinde farklılaşan mikrosporidian türlerinin albendazole karşı çok fazla hassas olabileceği görülmüştür (61). Albendazol, E. bieneusi intestinal enfeksiyonunda sınırlı etki göstermekte, enfeksiyonu ortadan kaldıramamakta fakat diyareyi hafiflemektedir. Buna karşın E. intestinalis vakalarında enfeksiyonun ve semptomların ortadan kaldırılmasında etkisinin fazla olduğu bildirilmiştir (61).

Albendazol, fumagillin, 5 fluorourasil, siprofloksasin, oksibendazol ve propamidin izetionat'ın hücre kültürlerinde E.cuniculi'nin gelişimini inhibe ettiği saptanmış; ayrıca, klorokin, peflosin, azitromisin, rifambutin ve tiabendazolün ise yüksek konsantrasyonlarda etkili olduğu bildirilmiştir (62).

\section{Keratokonjonktivit Tedavisi}

Mikrosporidial stromal keratit vakalarında cerrahi yöntemler kullanılmış; ancak tedavi etkinliğinin sınırlı olduğu belirtilmiştir. Bilinen çeşitli antimikrobiyal, lubrikant ve antienflamatuar ajanlar mikrosporidia ile enfekte oküler tedavide kullanılmaktadır. Itrakonazolün, Encephalitazoon spp. ile kornea tutulumunda kısmen etkili olduğu belirtilmiştir (63). TMP-SMX'ün, mikrosporidial ishallerde sınırlı etkiye sahip olmasına rağmen oküler tutulumda topikal kullanımın fayda sağlamadığı gösterilmiştir (64).

Yüzeyel keratokonjunktivit tedavisinde; topikal propamidin izetionat ve topikal itrakonazol ile birlikte sistemik oral triazol, flukonazol, tiabendazol ve albendazol kullanılmışsa da son zamanlar- da en ümit verici ilacın topikal fumagillin olduğu kabul edilmektedir. Keratokonjunktivitli iki AIDS'li hastada topikal fumagillin uygulanmış ve sınırlı bir bölgede enfeksiyonun azaldığı belirtilmiştir (6).

\section{Sistemik Enfeksiyonlarda tedavi}

Intestinal, üriner sistem, nazal mukoza ve oküler tutulumun bulunduğu bir sistemik mikrosporidiozis vakasında albendazolün etkili olduğu bildirilmiştir. Albendazol dışında; fumagillin, benomil, toltrazuril'inde etkili olduğu belirtilmektedir. E. bieneusi ile enfekte olan ve dissemine gelişen HIV pozitif bir hastada parazit, dışkı, deudonal biyopsi, nasal mukoza ve balgamda transmisyon elektron mikroskobisi kullanılarak tespit edilmiş ve albendazole ile tedavi edilmesi sonrasında ilerleyen semptomların kaybolduğu ayrıca parazitin eradikasyonunu sağlandığı belirtilmiştir (65).

\section{Korunma ve Kontrol}

Insan mikrosporidia enfeksiyonlarının kaynağı tam olarak tanımlanamamıştır. Son zamanlarda, insan-insan, hayvan-insan olarak bulaşmanın olduğu gösterilmiştir. Tam olarak açıklanamamakla birlikte, insanlara vektör veya ara konaklar vasıtasıyla da geçişin olabileceği bildirilmektedir. Son zamanlarda yapılan çalışmalarla, E. intestinalis'in lağım suları ile, E. bieneusi'nin yer altı ve içme suları ile, V. corneae'nın ise içme suları yoluyla bulaşacabileceğ doğrulanmıştır. Mikrosporidiaların sporları; dış ortama oldukça dayanıklı ve suda uzun süre canlı kalabilmektedirler. Ayrıca çok küçük oldukları için su filtrelerinden de geçebilmektedirler $(6,25)$. Çevrede nem ve sıcaklığa bağlı; aylarca hatta yıllarca canlı kalabilmekte, hastane ortamında $\left(22^{\circ} \mathrm{C}\right)$ sporlar en az bir ay yaşayabilmektedir. Bu nedenle korunma ve kontrol yöntemlerini şu şekilde sıralanabilir;

Fekal-oral yolla bulaşma söz konusu ise; kişisel hijyene, özellikle el temizliğine önem verilmelidir. Çeşitli vücut sıvılarında enfektif sporlar bulanabileceğinden özellikle hastanelerde bu duruma dikkat edilmelidir. Konjonktivit ve diğer göz enfeksiyonları açııından kirli ellerle gözlere dokunulmamalıdır. Ayrıca evde hazırlanan lens solüsyonları kullanımamalıdır.

Yeterli konsantrasyonda; dezenfektanlarla 30 dakikada, kaynatılarak 5 dakikada, $120^{\circ} \mathrm{C}^{\prime}$ de otoklavda sporlar canlılığını yitirmektedir. Sporların bulunabileceği yerlerin en az 30 dakika dezenfektanlarla (\%70 Etanol, \%0.3-1 Formaldehit, \%1 Hidrojen Peroksit, \%1 NaOH) temizlenmesi, enfekte maddelerin kaynatılması veya $120^{\circ} \mathrm{C}$ 'de 10 dakika otoklavlanmasının etkili olduğu bildirilmiştir. Dondurmak dezenfeksiyonda etkili değildir. Bütün bunlara rağmen etkili korunma stratejilerinin geliştirilmesi sınırlı olmaktadır $(11,65)$.

\section{SONUÇ}

Mikrosporidialar omurgalı ve omurgasız geniş yelpazede konak seçiciliği gösteren, mikrospora şubesi içerisinde yer alan, küçük, spor oluşturan, zorunlu hücre içi parazitidir. Bulaşma kişiden kişiye direkt olduğu gibi, su, süt, yiyecek, homoseksüel ilişki, yüzme havuzu suları, hayvan ve vektörler aracılığıyla da gerçekleşmektedir. Klinik semptomlar, enfeksiyonun lokalizasyonu ve konağın immun yanıtına göre değişmektedir. Diyareden, sistemik enfeksiyonlara kadar çok farklı kliniğe sebep olan bu parazitin sporları dezenfektanlarla 30 dakikada, kaynatılarak 5 dakikada öldüğü gibi, $120{ }^{\circ} C^{\prime}$ de otoklavlanarak da canlılığını yitirmektedir. 


\section{Çıkar Çatışması}

Yazarlar herhangi bir çıkar çatışması bildirmemişlerdir.

Hakem değerlendirmesi: Dış bağımsız.

\section{Yazar Katkıları}

Fikir - S.Y., Ö.K.; Tasarım - S.Y., S.K.; Denetleme - S.Y.; Kaynaklar Ü.Ç.; Malzemeler - Ü.Ç., Ü.K.; Veri toplanması ve/veya işlemesi Ü.Ç., B.H.; Analiz ve/veya yorum - S.S., S.K.; Literatür taraması Ü.Ç., B.H.; Yazıyı yazan - Ü.Ç., B.H.; Eleştirel Inceleme - S.S., Ö.K.; Diğer - S.Y., Ü.Ç.

\section{Conflict of Interest}

No conflict of interest was declared by the authors.

Peer-review: Externally peer-reviewed.

\section{Author Contributions}

Concept - S.Y., Ö.K.; Design - S.Y., S.K.; Supervision - S.Y.; Funding - Ü.Ç.; Materials - Ü.Ç., Ü.K.; Data Collection and/or Processing - Ü.Ç., B.H.; Analysis and/or Interpretation - S.S., S.K.; Literature Review - Ü.Ç., B.H.; Writing - Ü.Ç., B.H.; Critical Review Ü.Ç., B.H.; Other - S.Y., Ü.Ç.

\section{KAYNAKLAR}

1. Franzen C, Muller A. Molecular techniques for detection, species diferentiation, and phylogenetic analysis of microsporidia. Clin Mic Rev 1999; 12: 243-85.

2. Keeling PJ, Fast NM. Microsporidia: biology and evolution of highly reduced intracellular parasites. Ann Rev Microbiol 2002; 56: 93-116. [CrossRef]

3. Didier ES, Weiss LM. Microsporidiosis: current status. Curr Opin Infect Dis 2006; 19: 485-92. [CrossRef]

4. Weber R, Bryan RT, Schwartz DA, Owen RL. Human Microsporidial infections. Clin Microbiol Rev 1994; 7: 426-61.

5. Keohane EM, Weiss LM. The structure, Function and Composition of the Microsporidian Polar Tube. Wittner M, Weiss LM editors. The Microsporidia and Microsporidiosis. Washington: AMS pres; 1999.p.196-224.

6. Curry A, Beeching NJ, Gilbert JD, Scott G, Rowaland PL, Currie BJ. Trachipleistophora hominis infection in the myocardium and skeletal muscle of a patient with AIDS. J Infect 2005; 51: 139-44. [CrossRef]

7. OK ÜZ, Limoncu ME. Microsporidiosis. Özcel MA, Özbel Y, Ak M, editors. Özcel'in Tıbbi Parazit Hastalıkları. İzmir: Meta basım; 2007.p.397-410.

8. Joseph J, Vemuganti GK, Sharma S. Microsporidia: emerging ocular pathogens. Indian J Med Microbiol 2005; 23: 80-91. [CrossRef]

9. Didier Es, Stowall ME, Green LC, Brindley PJ, Sestak K, Didier PJ. Epidemiology of microsporidiosis: sources and modes of transmission. Veter Parasitol 2004; 126: 145-66. [CrossRef]

10. Curry A. Microsporidiosis. Cox FEG, Wakelin D, Gillespie SH, Despommier DD, editors. Topley and Wilson's Microbiology and Microbial Infections; Parasitology. Washinghton: ASM pres; 2005.p.529-55.

11. Karaman Ü. İnsanlarda microsporidia'ların epidemiyolojisi (malatya ili örneği), doktora tezi, Malatya, 2007.

12. Dunn AM, Smith JE. Microsporidian life cycles and diversity: the relationship between virulence and transmission. Microbes Infect 2001; 3: 381-8. [CrossRef]

13. Franzen C. Microsporidia: how can they invade other cells? Trends in Parasitology 2004; 20: 275-9. [CrossRef]
14. Franzen C. How do Microsporidia invade cells?. Folia Parasitologica 2005; 52; 36-40.

15. Aksoy Ü, Usluca S. Microsporidiosis ve immunolojisi. Özcel MA, Ínci A, Tugay N, Köroğlu E, editors. Tibbi ve Veteriner Immunoparazitoloji. Izmir: Meta basım; 2007.p.102-20.

16. Franzen C, Müller A, Hartmann P, Salzbergr B. Cell Invasion and intrcellular fate of Encephalitozion cuniculi (Microsporidia). Parasitology 2005; 130: 285-92. [CrossRef]

17. Atambay M, Karaman Ü, Daldal N, Çolak C. Inönü Üniversitesi Turgut Özal Tıp Merkezi Parazitoloji Laboratuvarına Gelen Erişkin Hastalarda Microsporidium Görülme Sıklığı. Türkiye Parazitol Derg 2008; 32: 113-5.

18. Karaman Ü, Atambay M, Daldal N, Çolak C. Kanser Tanısı Almış Hastalarda Microsporidium Görülme Sıklığı. Türkiye Parazitol Derg 2008; 32: 109-12.

19. Türk S. İshalli Olgularda Mıcrosporıdıa Sıklığının Farkı Boyama Yöntemleriyle Araştırılması, Yüksek Lisans Tezi, Ankara, 2010.

20. Yazar S, Eser B, Yalçın Ş, Şahin I, Koç N. Acase of Pulmonary Microsporidiasis in an Acute Myeloblastic Leukemia (AML)- M3 Patient. Yosei Med J 2003; 44: 146-9.

21. Büget E, Büyükbaba-Boral Ö, Kırkoyun-Uysal H, Nazlıcan Ö, Öğüt T, Şengür G. Türkiye'de bir AIDS hastasında ilk mikrosporidiyaz ve solunum sistemini tutan ilk kriptosporidiyaz olgusu. Türk Mikrobiyol Cem Derg 2000; 30: 166-70.

22. Sancak B, Akyön Y. Microsporidia: Genel özellikleri, infeksiyonları ve laboratuvar tanısı. Microbiol Bült 2005; 39: 513-22.

23. Daldal N, Alkan MZ. Isosporiosis, sarcocycystosis, microsporidiosis. Özcel MA, editor. Immun Yetmezlikte Önemi Artan Parazit Hastalakları. İzmir; Türkiye Parazitol Dern Yay: 1995.p.51-67.

24. Franzen C, Müller A. Microsporidiosis: human diseases and diagnosis. Micro Infec 2001; 3: 389-400. [CrossRef]

25. Garcia LS. Diagnostic Medical Parasitology. Washington, USA ASM Press.p.33-46.

26. Kokoskin E, Gyorkos TW, Camus A, Cedilotte L, Purtill T, Ward B. Modified Technique for efficent detection of microsporidia. J Clin Microbiol 1994; 32: 1074-5.

27. Carter PL, MacPherso DW, McKenzie RA. Modified Technique to recover microsporidian spores in sodium acetate-acetic acid-formalin-fixed fcal samples by ligt microscopy and correlaion with trasmission electron microscopy. J Clin Microbiol 1996; 34: 2670-3.

28. Ryan NJ, Sutherland G, Coughlan K, Globan M, Doultree J, Marshall $J$, et al. A new trichrome ble stain for dete ction of microsporidial species in urine, stoll and nasopharyngeal specimens. J clin microbiol 1993; 31: 3264-9.

29. Karaca Ö, Rota S. İnsan microsporidial infeksiyonları. Türk Microbiyol Cem Derg 1996; 26: 142-50.

30. Tuli L, Singh DK, Gulati AK, Sundar S, Mohapatra TM. A multiattribute utility evaluation of different methods for the detection of enteric protozoa causing diarrhea in AIDS patients. BMC Microbiol 2010; 10: 11. [CrossRef]

31. Miller AA, Simakova AV. Use of the OTE-staining method for ultrathin sections on the example of microsporidia (Protozoa: Microsporidia). Tsitologiia 2009; 51: 741-7.

32. Chioralia G, Trammer T, Kampen H, Seitz H. Relevant criteria for detecting microspordia in stool specimens. J Clin Microbiol 1998; 36: 2279-83.

33. Joseph J, Murthy S, Garg P, Sharma S. Use of different stains for microscopic evaluation of corneal scrapings for diagnosis of microsporidial keratitis. J Clin Microbiol 2006; 44: 583-5. [CrossRef]

34. Green LC, LeBlanc PJ, Didier ES. Discrimination brween viable and dead Encephalitozoon cuniculi (microsporidian) spores by dual staining with sytox gren and calcofluor white M2R. J Clin Microbiol 2000; 38: 3811-4.

35. Field AS, Marriott DJ, Hing MC. The Warthin-Starry stain in the diagnosis of small intestinal microsporidiosis in HIV-infected patients. Folia Parasitol (Praha) 1993; 40: 261-6. 
36. Mathis A, Weber R, Deplazes P. Zoonotic potential of the microsporidia. Clin Microbiol 2005; 18: 423-45. [CrossRef]

37. Accoceberry I, Thellier M, Desportes-Livage I, Achbarou A, Biligui S, Danis $\mathrm{M}$, et al. Production of monoclonal atibodies directed against the Microsporidium Enterocytozoon bieneusi. J Clin Microbiol 1999; 37: 4107-12

38. Franzen C, Müller A, Hartmann P, Salzbergr B. Quantitatin of Microsporidia in cultured cell by flow cytometry. Cytometry A 2004; 60: 107-14. [CrossRef]

39. Didier ES, Didier PJ, Friedberg DN, Stenson SM, Orenstein JM, Yee $\mathrm{RW}$, et al. Isolation and characterization of a new human microsporidian, Ecephalitozoon hellem (n.sp), from three AIDS patients with keratoconjunctivitis. J Infect Dis 1991; 163: 617-21. [CrossRef]

40. Ghosh K, Weiss LM. Molecular diagnostic tests for microsporidia. Interdiscip Perspect Infect Dis 2009; 2009: 926521.

41. Monteiro L, Bonnemaison D, Vekris A, Petry KG, Bonnet J, Vidal R, et al. Complex polysaccharides as PCR inhibitors in feces: helicobacter pylori model. J Clin Microbiol 1997; 35: 995-8.

42. Subrungruan I, Mungthi M, Chavalitshewinkoon-Petmit P, Rangsi R, Naaglor T, Leelayoova S. Evaluation of DNA extraction and PCR methods for detection of Enterocytozoon bienuesi in stool specimens. J Clin Microbiol 2004; 42: 3490-4. [CrossRef]

43. Graczyk TK, Johansson MA, Tamang L, Visvesvara GS, Moura LS, DaSilva AJ, et al. Retrospective species identification of microsporidian spores in diarrheic fecal samples from human immunodeficiency virus/AIDS patients by multiplexed fluorescence in situ hybridization. J Clin Microbiol 2007; 45: 1255-60. [CrossRef]

44. Wang Z, Orlandi PA, Stenger DA. Simultaneous detection of four human pathogenic microsporidian species from clinical samples by oligonucleotide microarray. J Clin Microbiol 2005; 43: 4121-8. [CrossRef]

45. Breton J, Bart-Delabesse E, Biligui S, Carbone A, Seiller X, OkomeNkoumou $M$, et al. New highly divergent rRNA sequence among biodiverse genotypes of Enterocytozoon bieneusi strains isolated from humans in Gabon and Cameroon. J Clin Microbiol 2007; 45: 2580-9. [CrossRef]

46. Santín M, Cortés Vecino JA, Fayer R. Enterocytozoon bieneusi genotypes in dogs in Bogota, Colombia. Am J Trop Med Hyg 2008; 79: 215-7.

47. Da Silva AJ, Schwartz DA, Visvesvara GS, Moura H, Slemenda SB, Pieniazek NJ. Sensitive PCR diagnosis of infections by Enterocytozoon bieneusi (microsporidia) using primers based on the region coding for small-subunit rRNA. J Clin Microbiol 1996; 34: 986-7.

48. Zhu X, Wittner M, Tanowitz HB, Kotler D, Cali A, Weiss LM. Small subunit rRNA sequence of Enterocytozoon bieneusi and its potential diagnostic role with use of the polymerase chain reaction. $J$ Infect Dis 1993; 168: 1570-5. [CrossRef]

49. Carville A, Mansfield K, Widmer G, Lackner A, Kotler D, Wiest P, et al. Development and application of genetic probes for detection of Enterocytozoon bieneusi in formalin-fixed stools and in intestinal biopsyspecimens from infected patients. Clin Diagn Lab Immunol 1997; 4: 405-8.

50. Velasquez JN, Carnevale S, Guarnera EA, Labbe JH, Chertcoff A, Cabrera MG, et al. Detection of the microsporidian parasite Enterocytozoon bieneusi in specimens from patients with AIDS by PCR. J Clin Microbiol 1996; 43: 3230-2.
51. David F, Schuitema AR, Sarfati C, Liquory O, Hartskeerl RA, Derouin $F$, et al. Detection and species identification of intestinal microsporidia by polymerase chain reaction in duodenal biopsies from human immunodeficiency virus-infected patients. J Infect Dis 1996; 174: 874-7. [CrossRef]

52. Weiss LM, Zhu X, Cali A, Tanowitz HB, Wittner M. Utility of microsporidian rRNA in diagnosis and phylogeny:a review. Folia Parasitol 1994; 41: 81-90.

53. Da Silva AJ, Slemenda SB, Visvesvara GS, Schwartz DA, Wilcox CM, Wallace $S$, et al. Detection of Septata intestinalis (microsporidia) cali et al. 1993 using polymerase chain reaction primers targeting the small subunitribosomal RNA coding region. Mol Diagn 1997; 2: 47-52. [CrossRef]

54. Visvesvara GS, Leitch GJ, Da Silva AJ, Croppo GP, Moura H, Wallace $\mathrm{S}$, et al. Polyclonal and monoclonal antibody and PCR-amplified small-subunit rRNA identification of a microsporidian, Encephalitozoon hellem, isolated from an AIDS patient with disseminated infection. J Clin Microbiol 1994; 32: 2760-8.

55. Visvesvara GS, Belloso M, Moura H, Da Silva AJ, Moura IN, Leitch GJ, et al. Isolation of Nosema algerae from the cornea of an immunocompetent patient. J Eukaryot Microbiol 1999; 46: 10 S.

56. Cali A, Takvorian PM, Lewin S, Rendel M, Sian CS, Wittner M, et al. Brachiola vesicularum, n. g., n. sp., a new microsporidium associated with AIDS and myositis. J Eukaryo Microbiol 1998; 45: 240-51. [CrossRef]

57. Saigal K, Sharma A, Sehgal R, Sharma P, Malla N, Khurana S. Intestinal microsporidiosis in India: A two year study. Parasitol Int 2013; 62: 53-6. [CrossRef]

58. Valencakova A, Halanova M. Immune response to Encephalitozoon infection review. Comp Immunol Microbiol Infect Dis 2012; 35: 1-7. [CrossRef]

59. Didier PJ, Phillips JN, Kuebler DJ, Nasr M, Brindley PJ, Stoval I ME, et al. Antimicrosporidial activities of fumagillin, TNP-470, Ovalicin and ovalicin derivatives in vitro and in vivo. Antimicrob Agents Chemoher 2006; 50: 2146-55. [CrossRef]

60. Molina JM, Oksenhendler E, Beauvais B, Sarfati C, Jaccard A, Derouin $F$, et al. Disseminated microsporidiosis due to Septata intestinalis in patients with AIDS: Clinical features and response to albendazole therapy. J Infect Dis 1995; 171: 245-9. [CrossRef]

61. Gross U. Treatment of Microsporidiosis Including Albendazole. Parasitol Res 2003; 90: 14-8.

62. Beauvais B, Sarfati C, Challier S, Derouin F. In vitro model to assess effect of antimicrobial agents on Encephalitozoon cuniculi. Antimicrob Agents Chemother 1994; 38: 2440-8.

63. Yee RW, Tio FO, Martinez JA, Held KS, Shadduck JA, Didier ES. Resolution of microsporidial epithelial keratopathy in a patient with AIDS. Ophthalmology 1991; 98: 196-201. [CrossRef]

64. Metcalfe TW, Doran RM, Rowlands PL, Curry A, Lacey CJ. Microsporidial Keratoconjunctivitis in a patient with AIDS. $\mathrm{Br} J$ Ophthalmol 1992; 76: 177-8. [CrossRef]

65. Rabaud C, Georges E, Guedenet JC, Allamagny E, May T, Canton P. Disseminated infestation of E. bieneusi a an HIV-infected Patient. Pathol Biol (Paris) 1999; 47: 576-8. 